\title{
Fulfilling the Promise of Batson: Protecting Jurors from the Use of Race-Based Peremptory Challenges by Defense Counsel
}

\author{
Audrey M. Fried $\dagger$
}

In Batson $v$ Kentucky, ${ }^{1}$ the Supreme Court held that a prosecutor violates the Equal Protection Clause when he challenges potential jurors on account of their race. In Georgia $v$ McCollum, ${ }^{2}$ the Court extended its prohibition on race-based peremptory challenges to defense attorneys. Basing his appeal on these cases, Arthur S. Huey, IV sought a new trial by claiming that his own defense attorney had violated McCollum. His request for a new trial was granted. ${ }^{3}$ However, when Eric Boyd made the same argument, his request for a new trial was denied. ${ }^{4}$

The different outcomes of these two cases reflect a disagreement between the Fifth and Seventh Circuits about whether a defendant is entitled to a new trial when her own attorney has exercised race-based peremptory challenges. Initially, the Fifth Circuit held that a court must grant a new trial to a defendant whose attorney exercised unconstitutional peremptories. ${ }^{5}$ However, in Mata $v$ Johnson, ${ }^{6}$ it recharacterized its decision, holding that a court must "choose that course of action that [it] believe[s] will do the least damage to the system and to the peoples' perception of it." The Seventh Circuit, also professing a concern for the

† B.A. 1995, University of Toronto; J.D. Candidate 1998, The University of Chicago.

1476 US 79, 89 (1986) ("[T] $]$ he Equal Protection Clause forbids the prosecutor to challenge potential jurors solely on account of their race or on the assumption that black jurors as a group will be unable impartially to consider the state's case against a black defendant.").

${ }^{2} 505$ US 42, 59 (1992) ('We hold that the Constitution prohibits a criminal defendant from engaging in purposeful discrimination on the ground of race in the exercise of peremptory challenges."). The Court has also extended the prohibition against discriminatory peremptory challenges to litigants in a civil trial. Edmonson v Leesville Concrete Co, 500 US 614, 616 (1991).

${ }^{3}$ United States $v$ Huey, 76 F3d 638, 639 (5th Cir 1996).

4 United States $v$ Boyd, 86 F3d 719, 724 (7th Cir 1996).

5 Huey, 76 F3d at 641 (After concluding that the trial court had erred when it did not find a Batson violation, the court held that "[s]uch error requires a new trial ....").

6 99 F3d 1261, 1270-71 (5th Cir 1996), vacated in part on rehearing, 105 F3d 209 (5th Cir 1997). Mata involved an ad hoc agreement between the prosecution and defense to exclude all black veniremembers from the jury without using peremptory challenges. However, the Mata court implied that courts should follow its approach whenever veniremembers have been excluded from a jury on the basis of race. 99 F3d at 1270. 
integrity of the criminal justice system, held that courts should never grant new trials to defendants who complain about unconstitutional peremptory challenges exercised on their own behalf. ${ }^{7}$ Both circuits emphasize the integrity of the justice system as if it were a principle independent of the equal protection rights of defendants and jurors. This is troublesome because the Supreme Court's decisions regarding race-based peremptory challenges indicate that the integrity of the criminal justice system depends, at least in part, on the system's ability to protect participants' constitutional rights.

The Supreme Court has consistently maintained that, by depriving defendants and jurors of their equal protection rights, race-based peremptory challenges harm defendants, jurors, and the criminal justice system. ${ }^{8}$ In response to these three harms, the Court has created a scheme of protections. This scheme, however, does not provide a perfect solution. Its principal weakness is its failure to provide adequate protection for prospective jurors.

In Powers $v$ Ohio, ${ }^{9}$ the Court recognized that because jurors face financial, legal, and informational barriers, they cannot effectively protect themselves from discriminatory peremptory challenges. The Court's solution to this problem was to grant third party standing to defendants and prosecutors to raise Batson claims on behalf of excluded jurors. This approach, however, leaves excluded jurors with no practical way to assert their constitutional rights when a defense attorney uses race-based peremptory challenges. The defense attorney is acting as the agent of the defendant when she violates Batson. Therefore, the defendant is an inappropriate representative of the excluded jurors. Conversely, the interests of the prosecutor and the excluded jurors are aligned; they all have an interest in preventing the defendant from improperly excluding jurors for the purpose of gaining an advantage at trial. However, while the prosecutor is an appropriate representative of jurors who have been improperly excluded by the defense attorney, prosecutors rarely raise Batson challenges. ${ }^{10}$

This Comment argues that courts should adopt the "No New Trial Rule" followed by the Seventh Circuit. Defendants should

7 Boyd, 86 F3d at 724 (holding that "the exercise of a peremptory challenge by the defense, in violation of Batson and McCollum, does not entitle the defendant to a new trial ....").

8 See Batson, 476 US at 86-87.

- 499 US 400, 414-15 (1991).

${ }^{10}$ See Kenneth J. Melilli, Batson in Practice: What We Have Learned About Batson and Peremptory Challenges, 71 Notre Dame I Rev 447, 458 (1996). 
not be rewarded with a new trial for their own unconstitutional behavior. Furthermore, excluded jurors are best served by a rule that does not encourage defendants to violate jurors' equal protection rights. Finally, the No New Trial Rule preserves the integrity of the criminal justice system by preventing manipulation of the system by defendants. By itself, however, the No New Trial Rule provides insufficient protection for jurors. Therefore, the Rule should be supplemented by an obligation on the part of judges to actively protect the interests of jurors by initiating Batson hearings sua sponte whenever the circumstances would permit a prosecutor to do so. This sua sponte obligation will also enhance the integrity of the criminal justice system by signaling the courts' commitment to uphold the Constitution.

Part I of this Comment reviews the Supreme Court cases that have imposed constraints on peremptory challenges in an effort to safeguard the equal protection rights of defendants and jurors and to preserve the integrity of the criminal justice system. Part II discusses the problems that arise when a defense attorney uses race-based peremptory challenges. Part III criticizes the approaches put forward by the Fifth and Seventh Circuits. Finally, Part IV proposes that courts should not grant defendants new trials because of their own attorneys' Batson violations. It further proposes that this No New Trial Rule should be combined with a sua sponte obligation on the part of judges to actively protect the rights of jurors. This proposal will protect the rights of jurors and the integrity of the criminal justice system without rewarding defendants for exercising unconstitutional peremptory challenges.

\section{PEREMPtory Challenges AND EQUAL PROTECTION}

Peremptory challenges allow parties to exclude jurors who cannot be excluded through a challenge for cause. The Supreme Court has concluded that peremptory challenges serve two beneficial purposes: they produce a more impartial jury than could be achieved through challenges for cause alone, and they help reassure parties that the jury is not biased against them. ${ }^{11}$ Although there is no constitutional right to peremptory challenges, ${ }^{12}$ the Supreme Court has characterized the peremptory challenge as "one of the most important of the rights secured to the accused."

\footnotetext{
"See Swain v Alabama, 380 US 202, 219 (1965).

${ }^{12}$ Stilson $v$ United States, 250 US 583, 586 (1919) ("There is nothing in the Constitution of the United States which requires the Congress to grant peremptory challenges."), cited with approval in Swain, 380 US at 219, and Batson, 476 US at 91.

${ }^{13}$ Swain, 380 US at 219, quoting Pointer $v$ United States, 151 US 396, 408 (1894).
} 
The Ninth Circuit recently reaffirmed the importance of peremptory challenges, holding that "the erroneous denial of a criminal defendant's right of peremptory challenge requires automatic reversal." 14

Despite their importance in ensuring a fair trial, however, peremptory challenges have fallen into disrepute. ${ }^{15}$ Ironically, the unlimited discretion historically conferred by peremptory challenges in order to facilitate the selection of an impartial jury also provides an opportunity for race and sex discrimination. In Batson, the Court found that the discriminatory use of peremptory challenges causes three harms. First, discriminatory challenges harm de-fendants by depriving them of their right to a jury selected according to nondiscriminatory criteria. ${ }^{16}$ Second, such challenges harm potential jurors by excluding them from participation in the legal system solely on the basis of their race or sex. ${ }^{17}$ Finally, discriminatory peremptories harm the integrity of the criminal justice system by "undermin[ing] public confidence in the [system's] fairness."18 As the Court subsequently explained, discriminatory jury selection "casts doubt over the obligation of the ... court to adhere to the law ...."19 In a series of cases starting with Batson, the Court has limited the exercise of peremptory challenges in an attempt to eliminate these three harms.

${ }^{14}$ United States $v$ Annigoni, 96 F3d 1132, 1134 (9th Cir 1996). For arguments supporting the preservation of peremptory challenges, see, for example, Jennifer Lee Urbanski, Casenote, Georgia v. McCollum: Protecting Jurors From Race-Based Peremptory Challenges But Forcing Criminal Defendants to Risk Biased Juries, 24 Pac L J 1887 (1993) (criticizing $M c$ Collum for limiting the use of peremptory challenges by defendants); Sharon Leigh Nelles, Note, Extending Batson v. Kentucky to the Criminal Defendant's Use of Peremptory Challenges: The Demise of the Challenge Without Cause, 33 BC L Rev 1081 (1992) (discussing the importance of the peremptory challenge for criminal defendants and the erosion of this device by the Batson line of cases).

${ }^{15}$ For example, in Minetos $v$ City University of New York, 925 F Supp 177, 183 (S D NY 1996), a district court found that peremptory challenges "by their very nature, invite corruption of the judicial process." The court went on to hold that "peremptory challenges per se violate equal protection." Id at 185.

For proposals to abolish peremptories, see, for example, Nancy S. Marder, Beyond Gender: Peremptory Challenges and the Roles of the Jury, 73 Tex L Rev 1041 (1995) (discussing the pros and cons of allowing peremptory challenges in light of the various functions of juries and concluding that peremptory challenges should be eliminated); Jere W. Morehead, When a Peremptory Challenge is No Longer Peremptory: Batson's Unfortunate Failure to Eradicate Invidious Discrimination from Jury Selection, 43 DePaul L Rev 625 (1994) (analyzing the development of peremptory challenges and suggesting that peremptory challenges be abolished).

${ }^{16} 476$ US at 86-87.

${ }^{17}$ Id at 87.

${ }^{18}$ Id.

${ }^{29}$ Powers, 499 US at 412. 
The Court first addressed racial discrimination in jury selection over one hundred years ago in Strauder $v$ West Virginia.$^{20}$ In that case, the Supreme Court held that racial discrimination in selecting members of the venire violates the equal protection rights of black defendants. ${ }^{21}$ In discussing the purposes of the Equal Protection Clause, the Court referred to the rights of both defendants ${ }^{22}$ and jurors. ${ }^{23}$ The Court's holding, however, was focused on the rights of defendants.

Ninety years later, the Batson Court extended Strauder's prohibition on discriminatory venire selection to the use of peremptory challenges in jury selection. In Batson, the Court held that when a prosecutor uses race-based peremptory challenges, she violates the Equal Protection Clause. ${ }^{24}$ The Court also held that a defendant may establish a prima facie case of prosecutorial discrimination on evidence solely from within the defendant's own trial. ${ }^{25}$ It thereby overruled part of Swain $v$ Alabama, an earlier decision that barred discriminatory peremptory challenges, but required a very high level of proof from defendants alleging discrimination. ${ }^{26}$ The Batson Court established the following procedure for proving Batson violations: (1) the defendant makes a prima facie showing of discrimination; (2) the prosecutor attempts to articulate a race-neutral explanation for the challenge; and (3) the court determines whether the challenge was in fact discriminatory. ${ }^{27}$ The Court justified the more lenient burden of proof by noting that the right to exercise peremptory chal-

\footnotetext{
20 100 US 303 (1879).

${ }^{21}$ Id at 310.

${ }^{2}$ Id (holding that the West Virginia statute "amount[ed] to a denial of the equal protection of the laws to a colored man when he is put up on trial for an alleged offence").

${ }^{23}$ Id at 308 (declaring that "[ $t$ ] he words of the [Fourteenth] [A]mendment . . . contain ... the right to ... exemption from legal discriminations, implying inferiority in civil soci-
} ety").

${ }^{24} 476$ US at 89.

${ }^{25}$ Id at 96 .

${ }^{26}$ Batson, 476 US at $100 \mathrm{n} \mathrm{25}$. The Swain Court held that a defendant could not establish discriminatory use of peremptory challenges from the record of a single case. Instead, the defendant had to show that:

the prosecutor in a county, in case after case, whatever the circumstances, whatever the crime and whoever the defendant or the victim may be, [wa]s responsible for the removal of Negroes who ha[d] been selected as qualified jurors by the jury commissioners and who ha[d] survived challenges for cause, with the result that no Negroes ever serve[d] on petit juries....

380 US at 223. See also Batson, 476 US at 92 (characterizing the Swain burden of proof as "crippling").

${ }^{27} 476$ US at 93-98. 
lenges is merely statutory and hence subordinate to the constitutional requirement of equal protection. ${ }^{28}$

In Batson, the Court explicitly listed the reasons for curtailing prosecutors' use of peremptory challenges: protection of the rights of defendants and jurors, and the need to safeguard the integrity of the justice system. ${ }^{29}$ The Court stressed the interrelatedness of the three harms, stating that "[public] respect for our criminal justice system and the rule of law will be strengthened if we ensure that no citizen is disqualified from jury service because of his race. ${ }^{\prime 30}$ Thus, according to the Court, the integrity of the criminal justice system depends on the enforcement of defendants' and jurors' equal protection rights.

In 1991, the Supreme Court expanded Batson's prohibition of race-based peremptories and shifted the focus to jurors' rights. In Powers $v$ Ohio, the Court held that "a criminal defendant may object to race-based exclusions of jurors effected through peremptory challenges whether or not the defendant and the excluded jurors share the same race. ${ }^{\text {"31 }}$ The Court reasoned that allowing defendants to object to the exclusion of jurors of a different race could provide an effective method of protecting jurors' rights. ${ }^{32}$ Later the same year, in Edmonson v Leesville Concrete $\mathrm{Co}^{33}$ the Court prohibited race-based peremptories in civil trials. The Court stated that regardless of whether the discrimination takes place in a civil or criminal proceeding the injury to the juror is the same. ${ }^{34}$ The Court used a "two-part analysis" in both Powers and Edmonson: first, it determined that race-based peremptory challenges by prosecutors and private litigants violate the equal protection rights of excluded jurors; ${ }^{36}$ second, it held that criminal defendants and civil litigants each have third party standing to assert the rights of excluded jurors. ${ }^{37}$ Thus, in both cases, the Court found an equal protection violation and standing. The need

\footnotetext{
28 Id at 98 .

2 Id at $86-87$.

so Id at 99.

31499 US at 402.

32 Id at 414 ("[T] here can be no doubt that petitioner will be a motivated, effective advocate for the excluded venirepersons' rights.").

${ }^{33} 500$ US 614, 616 (1991).

${ }^{34} \mathrm{Id}$ at 619 .

${ }^{35}$ Id at 618.

${ }^{36}$ Powers, 499 US at 409 (holding that the discriminatory exercise of a peremptory challenge by a prosecutor violates excluded jurors' equal protection rights); Edmonson, 500 US at 618-19 (holding that the discriminatory exercise of a peremptory challenge by a civil litigant violates excluded jurors' equal protection rights).

${ }^{37}$ Powers, 499 US at 415 (holding that criminal defendants have third party standing); Edmonson, 500 US at 630 (holding that civil litigants have third party standing).
} 
to vindicate the rights of improperly excluded jurors justified both extensions of Batson.

In Powers, the Court set out the test for determining whether to grant third party standing to a litigant:

[1] The litigant must have suffered an "injury in fact," thus giving him or her a "sufficiently concrete interest" in the outcome of the issue in dispute; [2] the litigant must have a close relation to the third party; and [3] there must exist some hindrance to the third party's ability to protect his or her own interests. ${ }^{38}$

The Powers Court held that a defendant seeking third party standing on behalf of improperly excluded jurors satisfies all three parts of this standing test. First, because the fairness of the process is cast into doubt, the defendant suffers an injury when the prosecutor discriminatorily excludes members of the venire from the jury. ${ }^{39}$ Second, "[v]oir dire permits a party to establish a relation, if not a bond of trust, with the jurors." The defendant and the excluded juror have a "congruence of interests" because they share an interest in eliminating racial discrimination from the courtroom. ${ }^{40}$ The Powers Court concluded that because the defendant satisfies this prong of the test, "it [is] necessary and appropriate for the defendant to raise the rights of the juror. ${ }^{p 11}$ Third, although an excluded juror has standing to bring suit on her own behalf, ${ }^{42}$ the Court found that, as a practical matter, jurors cannot adequately protect their own interests. ${ }^{43}$ In order to obtain injunctive or declaratory relief from the actions of an individual prosecutor, the excluded juror faces the difficult task of proving that the discrimination against her is likely to recur. ${ }^{44}$ Furthermore, individual jurors have little incentive to bring suit because the "financial stakes" are low, and the "economic burdens of litigation" are substantial..$^{45}$ Thus, because all three parts of the third party standing test were satisfied, the Powers Court concluded that criminal defendants have standing to vindicate the rights of excluded jurors. ${ }^{46}$

499 US at 411 (citations omitted).

${ }^{39}$ Id at $411-13$.

to Id at 413-14.

"Id at 414.

2 Carter v Jury Commission of Greene County, 396 US 320, 329-30 (1970).

${ }^{43}$ Powers, 499 US at 414-15.

"Id at 415 .

${ }^{4}$ Id.

${ }^{46}$ The Court made a similar argument in Edmonson, concluding that private litigants have third party standing to raise the rights of jurors excluded from a civil trial. Edmon- 
Both Powers and Edmonson continued the Supreme Court's pattern of discussing harm to the integrity of the justice system in the context of equal protection violations. For example, the Powers Court explained that "[a]ctive discrimination by a prosecutor during [the jury selection] process condones violations of the United States Constitution within the very institution entrusted with its enforcement, and so invites cynicism respecting the jury's neutrality and its obligation to adhere to the law." ${ }^{37}$ Such statements reflect the Court's increasing emphasis on the rights of jurors and the harm that violations of jurors' rights cause to the criminal justice system.

Edmonson resolved an additional issue-whether the exercise of peremptory challenges by private litigants is a "state action" subject to the constraints of the Equal Protection Clause. The Court answered this question in the affirmative, finding that peremptory challenges are "a right or privilege having its source in state authority. ${ }^{38}$ Thus, private litigants are state actors when they exercise peremptory challenges. ${ }^{49} \mathrm{~A}$ factor in the Court's decision was the "extent to which [itigants] rel[y] on governmental assistance and benefits. ${ }^{350}$ The Court noted that "[t]he trial judge exercises substantial control over voir dire in the federal system." ${ }^{\text {"51 }}$ This observation highlights the fact that both the powers and the responsibilities of individual parties are directly derived from those of the courts.

Relying on Powers and Edmonson, the Supreme Court held, in Georgia $v$ McCollum, ${ }^{52}$ that the Constitution prohibits criminal defendants from exercising race-based peremptory challenges. The Court found that, regardless of which party uses them, racebased peremptory challenges violate the equal protection rights of jurors and damage the integrity of the justice system..$^{53}$ The Court also found that a defense attorney's exercise of peremptory challenges constitutes state action. ${ }^{54}$ Finally, the Court reasoned that prosecutors have third party standing to raise the claims of im-

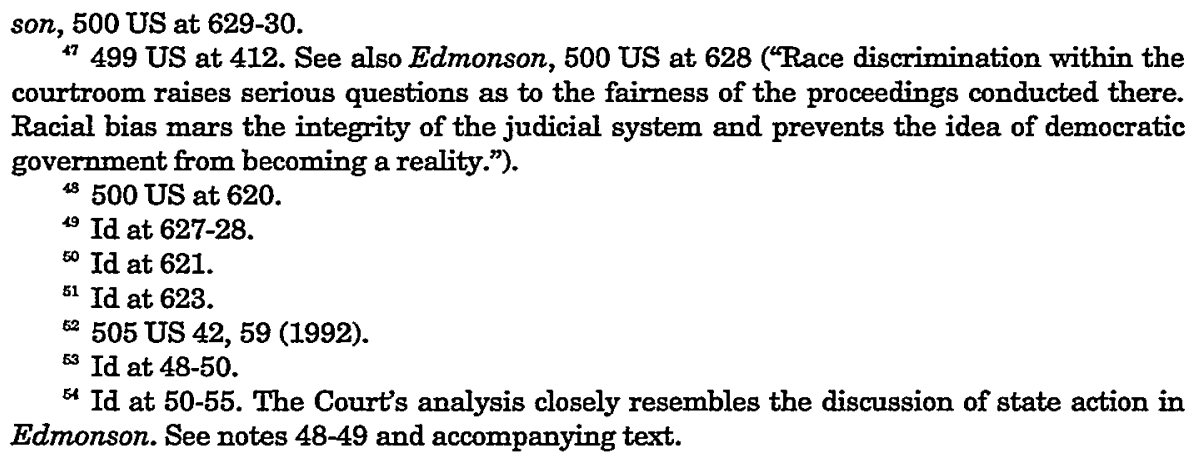

${ }^{17} 499$ US at 412. See also Edmonson, 500 US at 628 ("Race discrimination within the courtroom raises serious questions as to the fairness of the proceedings conducted there. Racial bias mars the integrity of the judicial system and prevents the idea of democratic government from becoming a reality.").

4300 US at 620 .

49 Id at 627-28.

${ }^{50} \mathrm{Id}$ at 621.

${ }^{51} \mathrm{Id}$ at 623 .

52505 US 42, 59 (1992).

${ }^{63}$ Id at $48-50$.

"F Id at 50-55. The Court's analysis closely resembles the discussion of state action in $E d m o n s o n$. See notes $48-49$ and accompanying text. 
properly excluded jurors. ${ }^{55}$ In this way, the Court extended Batson to encompass the exercise of peremptory challenges by the defense.

Once again, the Court rested its decision on the equal protection rights of excluded jurors. The opinion noted that "[r]egardless of who invokes the discriminatory challenge, there can be no doubt that the harm is the same-in all cases, the juror is subjected to open and public racial discrimination. ${ }^{.56}$ The Court also voiced concern for the integrity of the justice system, stating that "[s]election procedures that purposefully exclude AfricanAmericans from juries undermine public confidence [in the verdict-as well they should."57

The Court has not yet considered whether a court may permit a defendant to challenge her conviction because her own attorney used race-based peremptory challenges. In order to resolve that issue, a more detailed description of the harms caused by a defense attorney's Batson violation is required.

\section{A DEFENSE ATTORNEY'S BATSON VIOLATION AND THE THREE HARMS}

Taken together, these Supreme Court cases prohibit prosecutors, defense attorneys, and civil litigants from exercising racebased peremptory challenges. They also grant defendants, jurors, prosecutors, and civil litigants third party standing to raise Batson claims on behalf of excluded jurors. This framework aims to safeguard the rights of defendants, the rights of jurors, and the integrity of the criminal justice system. However, the fact that jurors must rely on others to raise their Batson claims ${ }^{58}$ limits the effectiveness of these safeguards. Because prosecutors rarely object to peremptory challenges, the McCollum Court's grant of third party standing to prosecutors does not provide jurors with adequate protection from race-based peremptory challenges by defense attorneys. ${ }^{59}$ This failure to protect the constitutional rights of jurors also damages the integrity of the criminal justice system. Judges could ameliorate these harms by raising Batson claims sua sponte.

Es Id at 55-56. The Court employed the same three-part test for standing that was used in Powers and Edmonson. See notes 38-46 and accompanying text.

${ }^{66}$ Id at 49.

${ }^{57}$ Id.

${ }^{58}$ See Powers, 499 US at 414-15.

59 See note 10 and accompanying text. 
A. Batson's First Harm: The Equal Protection Rights of Defendants

Discriminatory peremptory challenges by defense attorneys do not implicate the first harm identified by Batson. When a defense attorney uses a race-based peremptory challenge, she acts as an agent of the defendant. By making a discriminatory challenge through her attorney, the defendant waives the right to a jury selected by nondiscriminatory means. ${ }^{60}$ Therefore, the defense attorney does not violate the defendant's equal protection rights.

Two principles protect defendants from their own attorneys. First, a defendant has the right to represent herself pro se if she does not wish to be bound by her attorney's decisions. ${ }^{61}$ The Supreme Court has recognized, however, that defendants generally benefit from entrusting their defense to a legal expert. ${ }^{62}$ Second, if a defense attorney's unreasonable decisions prejudice the defendant's case, the defendant can have her conviction set aside for ineffective assistance of counsel. ${ }^{63}$

B. Batson's Second Harm: The Equal Protection Rights of Excluded Jurors

In contrast to defendants, jurors do suffer a violation of their equal protection rights when a defense attorney uses improper peremptory challenges. As the Supreme Court explained, while "[a]n individual juror does not have a right to sit on any particular petit jury ... he or she does possess the right not to be excluded from one on account of race." ${ }^{14}$ Furthermore, the Court noted that, "with the exception of voting, for most citizens the honor and privilege of jury duty is their most significant opportunity to participate in the democratic process. ${ }^{n 65}$ In addition, as the Supreme Court observed as early as 1879 , the exclusion of venirepersons from the jury because of their race "is practically a brand upon them, affixed by the law, an assertion of their inferi-

${ }^{\infty}$ Boyd, 86 F3d at 721-22 ("Boyd had a right to the verdict of a jury chosen without regard to race, but his lawyer waived that right on his behalf.").

${ }^{61}$ Faretta $v$ California, 422 US 806, 819 (1975) ( ${ }^{\circ}$ The Sixth Amendment grants the accused personally the right to make his defense.").

${ }^{62}$ Id at 834 ("It is undeniable that in most criminal prosecutions defendants could better defend with counsel's guidance than by their own unskilled efforts.").

${ }^{63}$ See Strickland $v$ Washington, 466 US 668, 691-92 (1984) ("[A]ny deficiencies in counsel's performance must be prejudicial to the defense in order to constitute ineffective assistance ....").

os Powers, 499 US at 409.

6s Id at 407 . 
ority, and a stimulant to that race prejudice which is an impediment to securing to individuals of the race that equal justice which the law aims to secure to all others. ${ }^{966}$ The equal protection rights of jurors have played an increasingly prominent role in the Supreme Court's peremptory challenge jurisprudence. ${ }^{67}$

As the Court observed in Powers, excluded jurors cannot effectively protect themselves against Batson violations. ${ }^{68}$ Jurors cannot object at the time of the exclusion because they are not parties to the jury selection process. ${ }^{69}$ Therefore, jurors have no opportunity to pursue the only remedy that would truly put them in their rightful position-that is, to be seated on the jury subsequent to a successful Batson challenge. Once the trial has begun, the only available remedy is a new trial. This remedy attempts to correct the harm to jurors as a group, but it does nothing to make the individual juror whole.

In addition to being unable to object at the time of the exclusion, jurors face severe obstacles in obtaining declaratory or injunctive relief. ${ }^{70}$ Because jurors do not usually face repeated discrimination, they are generally not entitled to an injunction. ${ }^{71}$ Furthermore, although at least one class action suit has challenged discriminatory procedures for selecting venires, ${ }^{72}$ veniremembers excluded from a jury will probably be unable to proceed as a class. ${ }^{73}$ For these reasons, excluded jurors are not in a good position to safeguard their own equal protection rights against race-based peremptory challenges.

The Court's solution to this problem has been to grant prosecutors standing to assert the rights of excluded jurors. ${ }^{74}$ However,

\footnotetext{
${ }^{56}$ Strauder, 100 US at 308.

${ }^{67}$ See Powers, 499 US 400; Edmonson, 500 US 614; McCollum, 505 US 42 . For a brief discussion of these cases, see Part I.

${ }^{68} 499$ US at 414-15.

${ }^{69}$ Id at 414.

${ }^{70} \mathrm{~A}$ Westlaw search conducted on September 8, 1997 yielded only one case in which an excluded juror has challenged discriminatory jury selection practices. In Shaw $v$ Hahn, 56 F3d 1128 (9th Cir), cert denied, 116 S Ct 418 (1995), a black woman who was excluded from a jury by peremptory challenge brought suit against the party that exercised the challenge, alleging that the peremptory violated her equal protection rights. However, the Ninth Circuit affirmed the district courts dismissal of the suit on the grounds that the issue was precluded by the ruling, in the original case, that the peremptory challenge was based on race-neutral reasons. 56 F3d at 1131 .

${ }^{71}$ See Powers, 499 US at 415.

${ }^{72}$ See Carter $v$ Jury Commission of Greene County, 396 US 320 (1970).

${ }^{73}$ For example, it is unlikely that enough veniremembers will be excluded to satisfy the numerosity prerequisite for a class action under the Federal Rules of Civil Procedure. See FRCP 23(a)(1) (A class action may proceed only if "the class is so numerous that joinder of all members is impracticable.").

"McCollum, 505 US at 56.
} 
this solution is inadequate because prosecutors rarely make Batson objections. A survey of reported cases decided after $\mathrm{McCollum}$ reveals that between June 18, 1992 (when McCollum was decided), and December 31, 1993, prosecutors raised only 4.25 percent of all reported Batson challenges. ${ }^{75}$ Prosecutors, thus, provide little protection for jurors' rights. ${ }^{76}$ Therefore, McCollum's solution is inadequate.

\section{Batson's Third Harm: The Integrity of the Criminal Justice System}

When a defense attorney uses race-based peremptory challenges, there are two potential threats to the integrity of the criminal justice system. First, as the Supreme Court has consistently noted, the integrity of the criminal justice system suffers when defendants or jurors are denied equal protection of the law. In Powers, the Court insisted that discrimination by a prosecutor during jury selection creates public cynicism toward the jury system. ${ }^{77}$ It further observed in McCollum and Edmonson that the same damage results whether a criminal defendant or a private litigant exercises the discriminatory challenge. ${ }^{78}$ Thus, the Supreme Court's peremptory challenge decisions emphasize that the integrity of the criminal justice system depends on the system's ability to protect the constitutional rights of its participants.

The Fifth and Seventh Circuits identify a second threat to the integrity of the criminal justice system-allowing a guilty defendant to "bootstrap his own violation of Batson into a new trial. ${ }^{\prime 79}$ Because a defendant's attorney acts as her agent, a court

${ }^{75}$ Melilli, 71 Notre Dame L Rev at 458 (cited in note 10). Criminal defendants made 88.20 percent of the objections. The remaining objections were made by civil litigants. Id.

${ }^{76}$ This is not to imply that prosecutors and defense attorneys necessarily commit an equal number of Batson violations.

77499 US at 412 . See note 47 and accompanying text.

${ }^{78}$ For criminal defense attorneys, see $M c$ Collum, 505 US at 50 ("Just as public confidence in criminal justice is undermined by a conviction in a trial where racial discrimination has occurred in jury selection, so is public confidence undermined where a defendant, assisted by racially discriminatory peremptory strikes, obtains an acquittal."). For civil litigants, see Edmonson, 500 US at 628 ("Race discrimination within the courtroom raises serious questions as to the fairness of the proceedings conducted there. Racial bias mars the integrity of the judicial system and prevents the idea of democratic government from becoming a reality."). See also Batson, 476 US at 99 ("In view of the heterogeneous population of our Nation, public respect for our criminal justice system and the rule of law will be strengthened if we ensure that no citizen is disqualified from jury service because of his race.").

${ }^{79}$ Boyd, 86 F3d at 725. The Fifth Circuit expressed the same concern (though perhaps less colorfully) in Mata, $99 \mathrm{F3d}$ at 1270 ("[D]f we should grant Mata a new trial, we may do even greater damage to the integrity of our judicial system; Mata would receive a benefit because of an error which he or his counsel invited, although Mata has never contended 
can attribute the attorney's race-based challenges to the defendant. ${ }^{80}$ As a result, a court that reverses a defendant's conviction because the defendant's own attorney used race-based peremptory challenges grants a major victory to an undeserving defendant. ${ }^{81}$ The Supreme Court, however, has not yet considered this "bootstrapping harm" to the integrity of the justice system.

\section{Yes, No, AND MAYBE: Two CiRCUITS, THREE ATTEMPTS}

In recent decisions, the Fifth and Seventh Circuits have adopted three strikingly different positions as to whether a defendant is entitled to a new trial because her own attorney used race-based peremptory challenges. In United States $v$ Huey, ${ }^{82}$ the Fifth Circuit held that a defendant should always get a new trial when her attorney violates Batson. In United States $v$ Boyd ${ }^{83}$ the Seventh Circuit held that a defendant should never get a new trial on such grounds. Then, in Mata $v$ Johnson, ${ }^{84}$ the Fifth Circuit recharacterized its earlier decision and held that under these circumstances, a defendant should sometimes get a new trial. Unfortunately, all three approaches fail to adequately protect jurors and the criminal justice system.

that he is innocent of the crime."). The concurrence in an earlier Fifth Circuit opinion made the point more bluntly:

Huey has gained an unwarranted advantage of the ruling as follows: 1) he uttered racial epithets in the course of committing a crime; 2) faced with mounting a defense before some individuals whose race he had insulted, he sought to preclude their service as jurors by requesting the court to remove all African Americans and all persons with Hispanic surnames; 3 ) when that request was denied, he used his peremptory strikes to preclude their service as jurors in violation of Batson; 4) although successfully purging the jury, he was nevertheless convicted; 5) he then appeals, complaining essentially of his own unconstitutional acts, and we now reverse his conviction and grant him a new trial on grounds that he created and benefited from.

Huey, 76 F3d at 642 (Jolly concurring).

${ }_{80}$ The Seventh Circuit emphasizes this point. See Boyd, 86 F3d at 721-22. See also notes 101-04 and accompanying text.

${ }^{81}$ The Supreme Court has not yet ruled on the issue of whether Batson violations that are not remedied at trial warrant automatic reversal on appeal. This Comment assumes that the appellate remedy for a Batson violation is automatic reversal because the Supreme Court's opinions have made that assumption. See, for example, Batson, 476 US at 100 ("If the trial court decides that the facts establish, prima facie, purposeful discrimination and the prosecutor does not come forward with a neutral explanation for his action, our precedents require that petitioner's conviction be reversed."). But see Eric L. Muller, Solving the Batson Paradox: Harmless Error, Jury Representation, and the Sixth Amendment, 106 Yale L J 93, 95-96 (1996) (arguing that, strictly speaking, Batson violations do not qualify as fundamental errors that require automatic reversal).

E2 76 F3d 638, 640 (5th Cir 1996).

${ }^{23} 86$ F3d 719, 724 (7th Cir 1996).

B4 99 F3d 1261, 1270 (5th Cir 1996). 


\section{A. Huey: The Fifth Circuit's New Trial Rule}

In United States $v$ Huey, two codefendants, Arthur S. Huey, IV, and Antonio A. Garcia, argued that their Batson rights had been violated when Huey's attorney used race-based peremptory challenges. At trial, Huey's attorney moved to exclude all blacks and all people with Hispanic surnames from the venire on the grounds that such jurors would be unable to reach an unbiased decision because the evidence against Huey included tapes and transcripts that contained racial epithets. The district court refused to allow these challenges for cause, but questioned the jurors as to whether they would be biased by the tapes or transcripts. None of the jurors who were questioned said that they would be biased. Huey's counsel then used his first three peremptory challenges to strike three black members of the venire. Both the prosecutor and Garcia's attorneys made Batson objections. The court, however, did not require Huey's counsel to respond. Huey's attorney then used his last two peremptories to strike black members of the venire. Again Garcia's attorney objected to no avail. The jury convicted both Huey and Garcia. ${ }^{85}$ 。

On appeal, the Fifth Circuit held that a court should grant a defendant a new trial when the defendant's own attorney used race-based peremptory challenges. ${ }^{86}$ Under this "New Trial Rule," the court found that Huey's attorney had violated Batson, and therefore granted a new trial to both defendants. ${ }^{87}$

In keeping with the Supreme Court's recent emphasis, the Fifth Circuit based its decision on the harm to excluded jurors. The court cited McCollum for the proposition that excluded jurors suffer the same harm whether it is the prosecution or the defense that discriminates against them. ${ }^{88}$ It reasoned that "the rationale articulated in Powers for holding that a defendant has standing to raise [Batson] claim[s] on behalf of prospective jurors is equally cogent and applicable in this situation." ${ }^{p 9}$ Therefore, the court granted both Huey and Garcia a new trial. "[O]nly by repudiating all results from such a trial," the court explained, "can public confidence in the integrity of this system be preserved ...."

This New Trial Rule ignores the fact that a Batson violation by a defense attorney is attributable to the defendant herself. When the defense attorney decides to exercise peremptory chal-

\footnotetext{
${ }^{85} 76$ F3d at 639-40.

${ }^{86}$ Id at 640 .

Id at 641 .

${ }^{8}$ Id at 640 , citing $M c$ Collum, 505 US at 49 .

76 F3d at 640 .

${ }^{20}$ Id at 641.
} 
lenges in a racially motivated manner, she waives her client's constitutional right to be tried by a jury selected through nondiscriminatory means. Due to this waiver, the defendant is not injured through a denial of her constitutional rights. Therefore, the defendant does not deserve a new trial.

The New Trial Rule permits defendants to champion the rights of excluded jurors when the Powers third party standing test is not satisfied. Huey provides no explanation for its assertion that "the rationale articulated in Powers for holding that a defendant has standing to raise [Batson] claim[s] on behalf of prospective jurors is equally cogent and applicable in this situation." ${ }^{\text {"1 }}$ On the contrary, the first and second prongs of the Powers test $^{92}$ are not satisfied. That is, the defendant does not suffer an injury when she "violates" her own rights, nor do the defendant and excluded jurors share an interest in eliminating discrimination from the trial. ${ }^{93}$ In fact, under the New Trial Rule, the defendant has an incentive to violate the rights of jurors in order to plant an error as a hedge against conviction. Thus, although it purports to protect the rights of jurors, the New Trial Rule creates perverse incentives that may actually increase the number of Batson violations.

The most striking problem associated with the New Trial Rule is that it harms the integrity of the criminal justice system. Even when defendants are not trying to plant errors, the integrity of the justice system is harmed when defendants violate jurors' rights and then benefit from that violation. While the Fifth Circuit panel did recognize the "irony in reversing Huey's conviction," ${ }^{\prime \prime 4}$ the concurrence put the matter more strongly, stating that "'the integrity of the jury system' . . is not well served by the result we reach today, because the public trust will be undermined when a convicted criminal can win a new trial based on his own abuse of the justice system. ${ }^{.95}$

\section{B. Boyd: The Seventh Circuit's No New Trial Rule}

In United States $v$ Boyd, Eric Boyd appealed his convictions for three armed robberies. As in Huey, the issue was "whether [a defense] counsel's inappropriate exercise of a peremptory challenge entitles [the defendant] to a new trial. ${ }^{296}$ During jury selec-

\footnotetext{
91 Id at 640 .

92 See note 38 and accompanying text.

${ }^{93}$ See Powers, 499 US at 411-14.

9 Huey, 76 F3d at 641 .

95 Id at 642 (Jolly concurring).

${ }^{96} 86$ F3d at 721.
} 
tion, Boyd's attorney used peremptory challenges to strike the only black member of the venire. Neither Boyd nor the prosecutor objected. The judge sentenced Boyd to six hundred and fifty months of imprisonment. ${ }^{97}$ Testimony at the sentencing hearing revealed that Boyd's attorney had acted on the basis of racial stereotypes, and that Boyd was aware of his attorney's discriminatory reasoning. ${ }^{98}$

Although the Seventh Circuit found that Boyd's attorney had violated Batson and McCollum, it refused to grant Boyd a new trial. The court explained that "steps the court takes at the defendant's behest are not reversible, ${ }^{, 99}$ even if they cause injuries to the rights of jurors and to the criminal justice system. ${ }^{100}$ The court placed great emphasis on the agency relationship between the defendant and his attorney, explaining that "[a] lawyer is the client's agent." ${ }^{\text {101 }}$ The court reasoned that, except in cases of ineffective assistance of counsel or when a personal right is involved, a lawyer's actions are attributable to her client. The court explained that the right to exercise peremptory challenges is not a personal one; rather, "decisions about when to challenge potential jurors-and when not to do so-are among the tactical choices committed to counsel."102 Therefore, the court held that a defense counsel's use of discriminatory peremptory challenges does not entitle the defendant to a new trial unless the challenges amount to ineffective assistance of counsel..$^{103}$ The court affirmed Boyd's conviction because it concluded that Boyd had waived his "right to the verdict of a jury chosen without regard to race."104

The court also criticized Huey's New Trial Rule. It was particularly concerned that "[m]any a defendant would like to plant

${ }^{97}$ Id.

${ }^{8}$ The following passage describes the sentencing testimony:

[Boyd's attorney] told the court that he believed that white jurors would defer to a black juror's judgment about a black defendant, and counsel did not want Boyd's fate to rest on his ability to convince a single juror. Boyd himself attributed a different stereotype to counsel: Boyd related that counsel told him that middle class blacks should be removed from the jury because they are especially likely to vote to convict lower class blacks accused of a violent crime.

Id.

${ }^{99}$ Id at 722.

${ }^{100}$ Id at 724 ("Because the rule serves interests other than those of the accused, the [Huey] court believed, a defendant can obtain a new trial by attacking his own decision. This is a non-sequitur.").

${ }^{101}$ Id at 721.

${ }^{102}$ Id at 724.

${ }^{103}$ Id. When the court applied this rule to Boyd's case, it found that the challenges had not amounted to ineffective assistance of counsel.

${ }^{104}$ Id at 722. 
an error and grow a risk-free trial: an acquittal is irrevocable under the double jeopardy clause, and a conviction can be set aside."105 Thus, the court worried that the Fifth Circuit's rule would create perverse incentives for defendants. Moreover, the court cautioned that "[g]iving a defendant a new trial because of his own violation of the Constitution would make a laughingstock of the judicial process."106 Based on these concerns about jurors' rights and the integrity of the criminal justice system, the court rejected the Fifth Circuit's New Trial Rule.

Boyd's "No New Trial Rule" reduces perverse incentives because it refuses to reward ${ }^{107}$ unconstitutional behavior. ${ }^{108}$ The rule also enables courts to avoid awarding a new trial to a defendant who has acted unconstitutionally. However, the No New Trial Rule does not affirmatively safeguard jurors' equal protection rights. It merely avoids creating perverse incentives that would compound the problem. As in all Batson cases, jurors face serious barriers to vindicating their own Batson rights. ${ }^{109}$ Furthermore, although prosecutors have standing to raise the claims of jurors who were improperly excluded by defense counsel, ${ }^{110}$ prosecutors rarely make Batson challenges. The No New Trial Rule does nothing to provide an adequate mechanism for protecting the equal protection rights of jurors.

In addition to providing jurors with inadequate protection for their constitutional rights, the No New Trial Rule impairs the integrity of the criminal justice system. Although this rule saves the system from the embarrassment of rewarding a defendant for unconstitutional behavior, its failure to safeguard jurors' equal protection rights has effects external to the jurors themselves. As the Supreme Court has noted, the integrity of the criminal justice system depends substantially on protecting defendants' and jurors' equal protection rights. ${ }^{111}$

${ }^{105}$ Id at $721-22$.

${ }^{106}$ Id at 725.

${ }^{107}$ Note that the "reward" is a new trial, not an acquittal.

${ }^{108}$ Recall that, when selecting a jury, parties are state actors subject to the Equal Protection Clause. See notes 48-49 and accompanying text. See also Edmonson, 500 US at 619-20 ("Although the conduct of private parties lies beyond the Constitution's scope in most instances, governmental authority may dominate an activity to such an extent that its participants must be deemed to act within the authority of government and as a result, be subject to constitutional constraints.").

${ }^{100}$ See Powers, 499 US at 414-15. See also notes $68-70$ and accompanying text.

${ }^{10} \mathrm{McC}$ Collum, 505 US at 56.

${ }^{111}$ See text accompanying notes 29-30. 


\section{Mata: The Fifth Circuit's Balancing of Harms Approach}

In Mata $v$ Johnson, ${ }^{112}$ the Fifth Circuit revisited the issue of whether a court should grant a new trial to a defendant because of her counsel's discriminatory jury selection practices. The facts of Mata differ slightly from those of Huey and Boyd. In Mata, the prosecution and defense agreed to exclude all eight of the black veniremembers without using peremptory challenges. The trial judge did not request a nondiscriminatory reason for the exclusions. ${ }^{113}$ Thus constituted, the jury sentenced Mata to death for the murder of a black prison guard at the Ellis Unit of the Texas Department of Corrections, where Mata was serving a sentence for a previous murder. On appeal, the Fifth Circuit treated the agreement between the prosecution and the defense as a species of peremptory challenge because "it would be ludicrous to believe that state actors could avoid the constitutional infirmity of racebased peremptory strikes by mutual agreement."114 Nevertheless, despite this discriminatory "peremptory challenge," the court affirmed Mata's conviction. ${ }^{115}$

The court reached its decision after recharacterizing Huey's New Trial Rule as a "Balancing of Harms" approach. This approach concentrates exclusively on minimizing harm to the integrity of the criminal justice system. The court rejected the need to consider harm to the rights of defendants. It agreed with the Seventh Circuit's assertion that the defendant, through defense counsel, had waived those rights. ${ }^{116}$ The court also rejected the need to consider the rights of jurors, reasoning that it could do nothing "to remedy the injury to the particular veniremembers who a decade ago were excluded from Mata's jury." concluded that when a defendant appeals her conviction on the grounds that her own attorney discriminated in selecting a jury, the principal consideration is the integrity of the criminal justice system. ${ }^{118}$ Under the Balancing of Harms test put forth in Mata, courts must "consider the facts peculiar to th[e] case, balance the competing harms to the system, and choose that course of action

\footnotetext{
11299 F3d 1261.

${ }^{113} \mathrm{Id}$ at 1264.

"I" Id at 1269.

${ }^{115}$ Id at 1273.

${ }^{116}$ Id at 1270 .

${ }^{117} \mathrm{Id}$.

${ }^{118}$ Id ("Our current concern, then, must be principally for the reputation and integrity of the system in general.").
} 
that [they] believe will do the least damage to the system and to the peoples' perception of it."'119

Mata illustrates the "competing harms to the system" that will likely arise whenever a defendant challenges her own attorney's discriminatory jury selection. On the one hand, leaving racial discrimination in jury selection unremedied undermines the integrity of the criminal justice system. On the other hand, granting a new trial to a guilty defendant who abused the system is also harmful. Applying its Balancing of Harms approach, the Mata court stated that the pre-Batson agreement reached at Mata's trial would not likely recur given that the values of Batson had since been firmly established. As a result, the court found that the need for deterrence was slight. ${ }^{120}$ The court contrasted the situation in Mata to that in Huey. There, the decision to grant Huey a new trial "did not significantly increase the financial or emotional burden on the community," since there was no question that the court would have to grant a new trial to Garcia, Huey's codefendant. ${ }^{121}$ Thus, because the need for deterrence was low and the community would be harmed by a reversal, the court decided not to grant Mata a new trial.

The Balancing of Harms approach collapses consideration of harm to jurors and harm to the justice system into one inquiry. This is possible because the integrity of the justice system depends in part on protecting jurors' rights. ${ }^{122}$ However, the system's integrity also depends on preventing strategic behavior by defendants. ${ }^{123}$ By considering jurors' rights within the framework of an integrity inquiry, the Fifth Circuit justified subordinating the rights of jurors to the system's interest in preventing an undeserving defendant from getting a new trial. The Supreme Court, however, has always referred to three separate harms. Therefore, courts should try to address each harm individually and not balance one against the others. This Comment proposes that the No New Trial Rule be coupled with a sua sponte obligation on the part of trial judges to demand race-neutral explanations for possible Batson violations. This proposed rule would both ameliorate the harm to jurors and safeguard the integrity of the criminal justice system.

${ }^{119}$ Id at 1270-71.

${ }^{20}$ Id at 1271.

${ }^{21}$ Id. The fact that over 20 percent of the adult residents in Walker County, where Mata murdered the prison guard, were affiliated with the prison would have compounded the community's emotional burden in this case. Id at 1264 .

${ }^{12}$ See notes 77-78 and accompanying text.

${ }^{123}$ See notes 79-81. 
IV. COMBINING THE NO NEW TRIAL RULE WITH A JUDICIAL OBLIGATION TO INVESTIGATE PEREMPTORY CHALLENGES SUA SPONTE

Courts should not grant new trials to defendants whose own attorneys violate Batson. A New Trial Rule would provide an incentive for defendants to violate the rights of jurors and damage the integrity of the criminal justice system. Furthermore, defendants would benefit from the unconstitutional misconduct of their own attorneys. On the other hand, the No New Trial Rule provides insufficient protection for jurors' rights and therefore undermines the integrity of the criminal justice system. For these reasons, the No New Trial Rule should be accompanied by a sua sponte obligation on the part of trial judges to request a raceneutral reason whenever they observe behavior that constitutes a prima facie case of discrimination. ${ }^{124}$ Once the judge has requested a race-neutral explanation, the usual Batson procedures should be followed. If the judge finds that Batson was violated, then she should either reinstate the improperly excluded juror or require jury selection to begin again. If the judge finds that Batson was not violated, then the trial should proceed. By recognizing this duty to raise Batson violations sua sponte, courts affirm their commitment to prevent "violations of the United States Constitution within the very institution entrusted with its enforcement." 125

The justification for this obligation to make sua sponte findings of prima facie discrimination is found in two sources. First, the Supreme Court has recognized that the trial judge plays an essential role in dismissing jurors peremptorily. For example, in Edmonson v Leesville Concrete Co, the Court stated:

Without the direct and indispensable participation of the judge ... the peremptory challenge system would serve no purpose. By enforcing a discriminatory peremptory challenge, the court has not only made itself a party to the [biased act], but has elected to place its power, property, and prestige behind the [alleged] discrimination. In so doing the

\footnotetext{
${ }^{124}$ The elements of a prima facie case of race discrimination are: (1) an attempt to remove members of a cognizable racial group from the venire; (2) a procedure that permits those "who are of a mind to discriminate" to do so (peremptory challenges constitute such a procedure); and (3) facts and circumstances that raise the inference of discrimination. Batson, 476 US at 96.

${ }_{12}$ Powers, 499 US at 412.
} 
government has . . . in a significant way . . . involved itself with invidious discrimination. ${ }^{126}$

Because the trial judge has the last chance to prevent the discriminatory challenge, her failure to do so implicates her in the prohibited discrimination. ${ }^{127}$

Second, all judges take an oath to uphold the Constitution. ${ }^{128}$ In order to be faithful to this oath, trial judges should intervene whenever an attorney attempts to violate Batson. ${ }^{129}$ As the Supreme Court explained in Powers, "[ $t]$ he courts are under an affirmative duty to enforce the strong . . . constitutional policies embodied in th[e] prohibition [of discrimination in jury selection]." 130

A number of district and state courts have acted sua sponte to prevent Batson violations. ${ }^{131}$ Furthermore, the Eighth and Ninth Circuits have implicitly supported a sua sponte obligation by suggesting that, in some circumstances, judges should require a race-neutral reason for all challenges of jurors who belong to a cognizable group, whether or not a party objects. ${ }^{132}$ Finally, sevtext.

${ }^{120} 500$ US at 624 (internal quotation marks omitted). See note 51 and accompanying

${ }^{2}$ See, for example, Lemley $v$ State, 599 S2d 64, 70 (Ala 1992) ("The notion that by allowing racial discrimination to occur, the trial judge actually becomes a part of that discrimination is . . applicable to the trial judge who, in a case with racial overtones, recognizes a racial pattern to counsel's peremptory strikes yet takes no steps to inquire into counsel's motivation.").

${ }^{123}$ Both federal and state judges are required by the Constitution to take an oath to "support the Constitution." US Const, Art VI, cl 3. The oath for federal judges is set out in 28 USC $\S 453$ (1994).

${ }^{12}$ See, for example, Brogden $v$ Maryland, 102 Md 423, 649 A2d 1197, 1198 (Md Ct Spec App 1994) (upholding sua sponte intervention by a trial judge who stated: "The panel may be acceptable to the parties, but I do not believe that the panel is acceptable to the court. It seems to me we have a very real Batson situation here.").

${ }^{130} 499$ US at 416.

${ }^{131}$ See, for example, Alexis $v$ Leporati, 1996 US Dist LEXIS 11705, *11 (D Mass) ("[T] $]$ his court considers that it is duty-bound to conduct a Batson inquiry whenever it finds that circumstances themselves establish a prima facie case of discrimination."); Lemley, 599 S2d at 69 ("[T] The trial judge, as the presiding officer of the court, should take the necessary steps to ensure that discrimination will not mar the proceedings in his courtroom."); Doe v Downers Grove, 834 F Supp 244, 248-50 (N D Ill 1992) (justifying sua sponte denial of race-based peremptory challenges), revd on other grounds by Doe $v$ Burnham, 6 F3d 476 (7th Cir 1993); Brogden, 649 A2d at 1199 ("A trial judge need not sit idly by when he or she observes what he perceives to be racial discrimination in the exercise of peremptory challenges."); New York $v$ Nelson, 625 NYS2d 176, 214 A2d 411, 411 (NY App Div 1995) ("The trial court properly noted, sua sponte, the prima facie existence of a Batson violation ...."); New York v Maisonet, 618 NYS2d 718, 209 A2d 297, 297 (NY App Div 1994) ("The record supports the trial court's sua sponte determination of the existence of a prima facie showing of gender discrimination ....”).

${ }^{122}$ See United States $v$ Johnson, 873 F2d 1137, 1140 n 3 (8th Cir 1989) ("[W]here the district court considers the issue to be close, conservation of judicial resources might well justify inquiry of the government attorney as to the reasons for making a strike."); United 
eral commentators have recently suggested that judges should act sua sponte to prevent the improper exercise of peremptory challenges. ${ }^{133}$

The most significant barrier to the adoption of a sua sponte obligation is that it would contravene the principle that failure to object constitutes waiver. Both the Seventh and the Fourth Circuits avoid intervening in jury selection absent an objection. ${ }^{134}$ However, waiver concerns, while valid, are not relevant to the scenario created by the current proposal for two reasons. First, the Seventh Circuit's use of past cases reveals that the court is concerned that appellate courts would be required to rule without the benefit of a record containing contemporaneous observations. ${ }^{135}$ However, a sua sponte obligation would require trial judges to make contemporaneous observations concerning the race-neutral reasons offered by the party exercising the challenge. Therefore, a sua sponte obligation would create a record for the appellate court to review.

Second, waiver is an inappropriate concept where, as here, the rights of third parties are concerned. Although our society is committed to an adversarial system of zealous advocacy, ${ }^{136}$ this

States $v$ Chinchilla, 874 F2d 695, 698 n 5 (9th Cir 1989) ("It might be advisable for the court and counsel to have a pre-selection in camera discussion in which the cognizable racial group is identified. Then during the course of jury selection, counsel could ask for a recess and explain in advance the reasons for an intended peremptory challenge of a member of that group.").

${ }^{133}$ See, for example, Christo Lassiter, The O.J. Simpson Verdict: A Lesson in Black and White, 1 Mich J Race \& L 69, 104 (1996) ("Batson . . . requires trial judges, upon defense motion or sua sponte, to deny peremptory strikes by the prosecutor in a criminal case unless the prosecutor articulates a race-neutral explanation for an apparent attempt to eliminate racial diversity in the jury."); Marder, 73 Tex L Rev at 1121 (cited in note 15) ("One possibility is that the judge might step in sua sponte ...."); Susan N. Herman, Why the Courts Love Batson: Representation-Reinforcement, Colorblindness, and the Jury, 67 Tulane L Rev 1807, 1853 (1993) ("ITt seems appropriate for the trial judge to raise a Batson problem sua sponte if a prima facie case against a cognizable racial group has developed.").

${ }^{134}$ See Burnham, 6 F3d at 481 ("Under Batson, a court should at least wait for an objection before intervening in the process of jury selection to set aside a peremptory challenge."); Clark $v$ Newport News Shipbuilding and Dry Dock Co, 937 F2d 934, 939 (4th Cir 1991) (Considering the defendant's first-time assertion of a Batson violation on appeal, the court held that " $[n]$ ] ither Batson nor its progeny suggests that it is the duty of the court to act sua sponte to prevent discriminatory exclusion of jurors.").

${ }^{135}$ Burnham, 6 F3d at 481. See United States v Pulgarin, 955 F2d 1, 2 (1st Cir 1992) ("[C]ontemporaneous objection is especially pertinent as to Batson claims."); Thomas $v$ Moore, 866 F2d 803, 805 (5th Cir 1989) ("Determining whether a prosecutor has acted discriminatorily in his use of a peremptory challenge depends greatly on the observations of the presiding judge.").

${ }^{136}$ Model Rules of Professional Conduct, Preamble, cl 2 (1996) ("As advocate, the lawyer zealously asserts the client's position under the rules of the adversary system."). However, the adversary system is not without exceptions. For example, judges are obligated to raise subject matter jurisdiction sua sponte. Mount Healthy City District Board of Educa- 
system often "fails to take into consideration the rights of third parties." ${ }^{\$ 137}$ When they exercise discriminatory peremptory challenges, defendants waive their own Batson rights. They should not, however, be allowed to waive the rights of jurors. As one commentator has suggested, "[t]he role of the trial judge must be expanded if the overly zealous advocate is to be tamed."138

An additional concern raised by the Seventh Circuit is that, in view of the importance of peremptory challenges, "[j]udges should invade a party's discretion to strike potential jurors only in narrow circumstances. ${ }^{p 139}$ While this principle is sound, a sua sponte obligation does not grant broad discretion to the trial judge to interfere with peremptory challenges. Rather, judges would only intervene when a prima facie case of discrimination exists. ${ }^{140}$ A prima facie case already triggers Batson challenges by defendants and prosecutors. Thus, the judge's sua sponte obligation interferes with peremptory challenges only to the extent already authorized by the Supreme Court.

The rule proposed in this Comment will function as follows. When objecting to an improper challenge by the defense counsel, the judge will stand in the shoes of the prosecutor. If the defense attorney acts in a manner that constitutes a prima facie case of discrimination, the judge has a duty to request a race-neutral reason for the peremptory challenge. The judge will then rule on the sufficiency of that reason. The judge's ruling will be reviewable on appeal, but will not constitute a reversible error. That is, appellate judges will have a sua sponte obligation ${ }^{141}$ to determine whether the trial judge's determination was erroneous. However, appellate judges will not grant the defendant a new trial if her own defense attorney violated Batson, even if the trial judge erred in accepting the race-neutral explanation.

tion v Doyle, 429 US 274, 278 (1977); MC \& LM Railway Co $v$ Swan, 111 US 379, 382 (1884). They are also obligated to recuse themselves sua sponte. 28 USC $\$ 455$ (a) (1994); Christiansen $v$ National Savings and Trust Co, 638 F2d 520, 534 (DC Cir 1982); United States $v$ Torkington, 874 F2d 1441, 1446 (11th Cir 1989).

${ }^{127}$ Paul Lowell Haines, Note, Restraining the Overly Zealous Advocate: Time for Judicial Intervention, 65 Ind L J 445, 448 (1990).

${ }^{138}$ Id at 462 .

${ }^{139}$ Burnham, 6 F3d at 481.

${ }^{140}$ See note 124 and accompanying text.

"This obligation arises from the same sources as that of the trial judge. The appellate judge's obligation is important because defendants will not have an incentive to raise the issue on appeal since they will not be granted a new trial regardless of the court's decision. Note, however, that the appellate judge will not be required to search for Batson problems in the record. Rather, the appellate judge should confine herself to reviewing the trial judge's ruling when the trial judge has acted sua sponte and should only review a failure to act sua sponte when that failure is obvious from the record. 
In the case of an improper challenge by the prosecutor, the trial judge will stand in the shoes of the defendant. Thus, a trial judge's erroneous denial of a Batson challenge leveled against the prosecutor will remain reviewable and reversible, regardless of whether the challenge is raised by the defense attorney or the trial judge. These procedures will minimize the three harms caused by race-based peremptory challenges by defense counsel. ${ }^{142}$

First, the proposed system will leave intact the defendant's protection against her own attorney. Courts will still have an obligation to grant new trials to defendants who received ineffective assistance of counsel. ${ }^{143}$

Second, the proposed system will increase the protection of jurors' rights but will not create incentives for defendants to act strategically. The only real remedy for improperly excluded members of the venire is for them to be seated on the jury after a successful Batson challenge. ${ }^{144}$ Therefore, it is important to provide incentives for judges to act at the time of the violation. There are many factors that provide these incentives: the judge's professionalism and sense of duty; the judge's concern for her reputation; informal methods of judicial discipline; ${ }^{145}$ and the appellate court's review of the trial judge's decisions. The willingness of trial judges to intervene sua sponte has been demonstrated in several cases. ${ }^{146}$ Because prosecutors represent jurors inadequately, this willingness is especially beneficial when the Batson violation is committed by the defense counsel. ${ }^{147}$ Therefore, a judicial sua sponte obligation will increase safeguards of jurors' equal protection rights at the most crucial stage in the process: when the harm can still be averted. ${ }^{148}$

\footnotetext{
${ }^{112}$ Of course, the trial judge's vigilance will also increase protection from discriminatory peremptories exercised by the prosecutor.

${ }^{14}$ See Part II.A.

${ }^{14}$ See Part II.B.

${ }^{145}$ See Charles Gardner Geyh, Disciplining the Federal Judiciary: Informal Methods of Judicial Discipline, 142 U Pa L Rev 243 (1993) (discussing eight methods of discipline, including informal actions of the chief circuit or district judge and informal actions of peer judges).

${ }^{14}$ See note 131. Note that these cases have come to our attention only because the sua sponte determination was challenged. Thus, this sampling of cases is probably underinclusive.

${ }^{147}$ See note 75 and accompanying text for a discussion of the inadequacy of prosecutors as representatives of excluded jurors.

${ }^{148}$ The Ninth Circuit presents a unique twist. In a recent case, the court, sitting en banc, held that "the erroneous denial of a criminal defendant's right of peremptory challenge requires automatic reversal." United States $v$ Annigoni, 96 F3d 1132, 1134 (9th Cir 1996). Therefore, in the Ninth Circuit, a judge's erroneous sua sponte denial of a peremptory would be reversible, but under this Comment's proposal, a judge's erroneous sua
} 
The proposed system would also eliminate perverse incentives for defendants. Combining the sua sponte obligation with the No New Trial Rule will preclude a court from granting a new trial to a defendant when her own attorney acted in a discriminatory manner. This would be true even when the judge, acting sua sponte, erroneously concluded that the challenge did not violate Batson. Under a rule which included the sua sponte obligation, but not the No New Trial Rule, the defendant might still succeed in planting an error. Although she would not have control over whether the judge raised the issue, the defendant would still have little to lose and much to gain from attempting to plant an error. Therefore, perverse incentives might still exist if a new trial were available. However, when the No New Trial Rule is combined with the sua sponte obligation, these problematic incentives are eliminated.

Finally, the proposed system will preserve the integrity of the criminal justice system along two dimensions. First, the No New Trial Rule will prevent defendants from bootstrapping their own Batson violations into a second chance for acquittal. Second, the sua sponte obligation will enhance public confidence in the fairness and integrity of the justice system. Judges will actually protect jurors from having their rights violated by the judicial system. Therefore, the integrity of the system will be increased insofar as that integrity depends on the ability of the system to protect the constitutional rights of its participants. Furthermore, judges will explicitly assume the responsibility for protecting jurors and the system. That undertaking will signal trial judges' commitment to uphold the Constitution and thus further enhance the integrity of the system.

Although the No New Trial Rule and sua sponte obligation will not prevent or remedy all race-based peremptory challenges, the combined rule and obligation have significant benefits. The proposal will eliminate incentives for defendants to violate the rights of jurors. It will increase the protection available to excluded jurors. And finally, it will enhance the integrity of the system by protecting jurors and enforcing the explicit judicial commitment to uphold the Constitution.

sponte denial of a Batson challenge to a peremptory would be reviewable, but not reversible. This asymmetry may give judges in the Ninth Circuit a slight incentive to err on the side of permitting peremptories. However, the incentives would be weaker in blatant cases of discrimination, since the reputational cost of allowing the challenge would increase and the chances of reversal would decrease. Therefore, even in the Ninth Circuit, a sua sponte obligation would provide significant protection for jurors. 


\section{CONCLUSION}

This Comment argues that a defendant should not be granted a new trial because her own attorney exercised racebased peremptory challenges. It further argues that judges should have a sua sponte obligation to raise Batson challenges when a prima facie case of discrimination exists. Together, this No New Trial Rule and sua sponte obligation will reduce harm both to excluded jurors and to the integrity of the criminal justice system.

The harm jurors suffer from race-based peremptory challenges will be reduced in two ways. First, the No New Trial Rule will avoid giving defendants an incentive to violate the rights of jurors in order to obtain a new trial. Second, the sua sponte obligation will increase the protection available to jurors by placing the responsibility for that protection with the vigilant trial judge.

The proposal will also enhance the integrity of the criminal justice system in two ways. First, the No New Trial Rule will prevent defendants from benefiting from their own unconstitutional behavior. Second, the sua sponte obligation will protect jurors and explicitly commit judges to upholding the Constitution. By safeguarding the equal protection rights of jurors and the integrity of the criminal justice system, the No New Trial Rule and the sua sponte obligation help to fulfill the objectives the Supreme Court put forth in Batson. 